\title{
Pengaruh Pemberian Konsentrasi IBA (Indole-3-Butyric Acid) dan Jumlah Mata Tunas terhadap Pertumbuhan Setek Indigofera sp
}

\author{
Effects of IBA (Indole-3-Butyric Acid) Concentration and Number of Buds \\ on Growth of Indigofera sp.
}

\author{
Muhammad Asifa Ussudur ${ }^{1}$, Ardian $^{1}$, Erwin Yuliadi ${ }^{1}$, Sri Ramadiana ${ }^{1}$ \\ ${ }^{1}$ Jurusan Agroteknologi Fakultas Pertanian Universitas Lampung, Bandar Lampung, 35141 \\ "Email: m.asifaussudur41@gmail.com
}

Disubmit: 14 September 2019 Direvisi: 25 Desember 2019 Diterima: 22 Januari 2020

\begin{abstract}
Abstrak: Indigofera $s p$. merupakan tanaman bergenus legum yang bermanfaat sebagai pakan hjiauan ternak dan sebagai penutup tanah. Kandungan $24,57 \%$ protein kasar, $90,68 \%$ bahan organik, $36,72 \%$ NDF (Neutral Detergen Fiber), 0,83\% fosfor, dan 1,23\% kalsium dapat dimanfaatkan untuk pakan ternak. Sebagai penutup tanah, Indigofera sp. dimanfaatkan sebagai pupuk hijau, mulsa, memperbaiki sifat fisik dan biologi tanah, mengendalikan gulma, menekan penggunaan herbisida, dan meningkatkan kesuburan tanah. Perbanyakan tanaman menggunakan biji sulit dilakukan karena struktur bijinya keras. Penelitian ini bertujuan untuk mengetahui pengaruh konsentrasi IBA dan jumlah mata tunas yang tepat untuk pertumbuhan setek Indigofera sp. Penelitian telah dilakukan bulan April Mei 2019 di Laboratorium Lapangan Terpadu Universitas Lampung. Perlakuan adalah konsetrasi IBA $(0,500,1000,1500$, dan 2000 ppm) dan jumlah mata tunas (1, 2, dan 3 mata tunas). Perlakuan disusun dalam Rancangan Acak Lengkap (RAL) pola faktorial terdiri dari 15 perlakuan dan 3 ulangan. Hasil penelitian menunjukkan bahwa konsentrasi IBA dan jumlah mata tunas berpengaruh nyata, sedangkan interaksi IBA dengan jumlah mata tunas tidak berpengaruh nyata terhadap pertumbuhan setek Indigofera sp. Konsentrasi IBA 500 ppm menghasilkan pengaruh perlakuan terbaik pada persentase setek berakar, panjang akar primer, jumlah tunas, jumlah daun, dan bobot segar tunas umur 6 minggu setelah tanam (MST). Setek 3 mata tunas menghasilkan perlakuan terbaik pada jumlah akar primer, panjang akar primer, bobot segar akar, bobot kering akar, jumlah daun, jumlah tunas, panjang tunas, bobot segar tunas, bobot kering tunas umur 6 dan 8 MST.
\end{abstract}

Kata kunci: Indigofera sp., IBA, mata tunas, setek, pakan hijauan ternak.

Abstract: Indigofera $s p$ is a legume-type plant which is useful as animal feed and as a ground cover. It consists of $24.57 \%$ crude protein, $90.68 \%$ organic matter, $36.72 \%$ NDF (Neutral Detergent Fiber), $0.83 \%$ phosphorus, and $1.23 \%$ calcium therefore it can be used as animal feed. As ground cover, Indigofera sp. used as green manure, mulch, improves physical and biological properties of the soil, controls weeds, suppresses the use of herbicides, and improves soil fertility. Plant propagation by using its seed is difficult because the seed structure is hard. This study aimed to determine the effect of the concentration of IBA and the number of buds that were appropriate for the growth of cutting of Indigofera sp. The research was conducted from April to May 2019 at the Integrated Field Laboratory, University of Lampung. The treatments were IBA concentrations (0,500, 1000, 1500, and 2000 ppm) and the number of buds (1,2, and 3 buds). The treatments were arranged in a completely randomized design (CRD) with factorial pattern consisting of 15 treatments and 3 replications. The result showed that the concentration of IBA and the number of buds had a significant effect, but the interaction of IBA with the number of buds did not significantly affect the growth of Indigofera sp. IBA concentration of $500 \mathrm{ppm}$ produced the best treatment effect on percentage of rooted cuttings, primary root length, number of shoots, number of leaves, and shoot fresh weight 6 weeks after planting (WAP). 3 buds cuttings produced the best treatment on the number of primary roots, primary root length, root fresh weight, root dry weight, number of leaves, number of shoots, shoot length, shoot fresh weight, dry shoots weight aged 6 and 8 WAP.

Keywords: Indigofera sp., IBA, Buds, Cutting, Feed. 


\section{PENDAHULUAN}

Indigofera spp. tersebar sebanyak 750 spesies di seluruh benua dan salah satu genus legum terbanyak ketiga (Schrire, 2009). Lingkungan adaptasi tanaman ini termasuk luas, di bidang pertanian dimanfaatkan sebagai pakan hijauan dan tanaman penutup tanah (cover crops) (Haseen, Pieterse and Rehman, 2004; Hassen, Rethman and Apostolides, 2006).

Sebagai sumber pakan hijauan ternak, menurut Herdiawan, Abdullah dan Sopandi (2014) menyatakan bahwa kandungan protein kasar Indigofera sp. sebesar $24,57 \%$ dengan perlakuan kontrol dan pemangkasan 60 hari dan serat kasar sebesar $25,85 \%$ dengan perlakuan cekaman berat $25 \%$ pada kapasitas lapang. Selain itu kandungan bahan organik Indigofera sp. sebesar 90,68\%, kandungan kalsium 1,23\%, NDF (Neutral detergen fiber) 36,72\%, dan fosfor 0,83\% (Badan Litbang Pertanian, 2011).

Pemanfaatan Indigofera sp. sebagai tanaman penutup tanah berjenis dapat bersimbiosis dengan bakteri Rhizobium sp. Rhizobium $\mathrm{sp}$ menfiksasi nitrogen dari udara lebih banyak sehingga dapat digunakan untuk pupuk hijau. Selain itu, nodul akar yang terbentuk oleh adanya bakteri Rhizobium sp. mengakibatkan $\mathrm{N}$ dapat tersedia dalam tanah dalam peningkatan status $\mathrm{N}$ dan bahan organik, serta penggunaan pupuk kimia dapat dikurangi. Kadar nitrogen yang tinggi pada daun serta kandungan karbon pada ranting digunakan sebagai mulsa alami untuk memperbaiki sifat fisik dan aktivitas biologi tanah, menekan penggunaan herbisida karena pertumbuhan gulma terhambat akibat adanya mulsa alami, dan meningkatkan kesuburan tanah. Menurut Hassen et al. (2007) tanaman ini toleran terhadap pemangkasan berat, salinitas tinggi, logam berat, tanah asam, dan kondisi kekeringan.

Melihat potensi yang dimiliki oleh tanaman Indogofera sp. yang cukup banyak, maka perlu ditingkatkan jumlah bibit yang tersedia. Secara umum dengan perbanyakan dilakukan secara generatif dan secara vegetatif. Perbanyakan menggunakan biji (geneartif) sulit dilakukan. Perlu perlakuan skarifikasi untuk memecah dormansi karena kulit bijinya yang keras (Christiana, 2018). Proses perkecambahan terhambat dikarenakan kulit biji yang keras menghambat masuknya air dan oksigen ke dalam biji (Haseen, Pieterse and Rehman, 2004; Hassen, Rethman and Apostolides, 2006).

Perbanyakan dengan cara setek atau vegetatif merupakan suatu alternatif yang perlu diperhatikan karena tekniknya sederhana yang dapat diterapkan dan lebih efisien. Penyetekan merupakan multipiklasi klon tanaman dengan menggunakan propagul dari akar, batang, atau akar. Perbanyakan dengan setek merupakan klonal regenerasi dari induknya (Dirr and Heuserr, 2006; Hartmann, 2014) sehingga diharapkan dapat memiliki sifa-sifat yang sama dengan induknya (Hartmann, 2014).

Setek batang adalah salah satu bahan untuk penyetekan. Penyetekan dari batang diharapkan lebih mudah tumbuh dengan adanya persediaan makanan (karbohidrat) yang cukup untuk pertumbuhan tunas dan akar (Ningsih, 2017). Jumlah mata tunas setek dapat mempengaruhi jumlah energi yang tersedia untuk pembentukan akar dan tunas karena kandungan ratio $\mathrm{C} / \mathrm{N}$. Menurut Tresniawati dan Saefudin (2006) bahwa panjang setek Jarak Pagar (Jatropha curcas L.) sepanjang $35 \mathrm{~cm}$ menghasilkan pertumbuhan bibit paling baik dari panjang setek lainya $(25 \mathrm{~cm}$ dan $15 \mathrm{~cm}$ ).

Upaya peningkatkan persentase hidup setek adalah dengan hormon IBA (indole-3-butyric acid). Hormon tersebut merupakan salah satu jenis hormon auksin 
untuk perangsang pembentukan akar (Nababan, 2009), mengatur pertumbuhan dan perkembangan tanaman, termasuk respon gaya gravitasi dan inisiasi akar lateral (Chun et al. 2003). Fungsi auksin adalah mendorong perpanjangan sel dan pembelahan sel, pembentukan akar atau tunas, differensiasi jaringan floem dan xilem, aktivitas kambium, induksi kalus, absisi (pengguguran daun), dan penghambatan mata tunas samping (Wattimena, 1992; Sandra, 2010).

Hasil penelitian Ramadiana (2008) pada aplikasi IBA konsentrasi 2000 ppm pada setek lidah mertua (Sansevieria trifasciata var. Lorentii) mampu mendapatkan pertumbuhan akar terbaik pada peubah jumlah akar dan pengukuran waktu muncul akar daripada konsentrasi lainnya (1000 ppm dan 4000 ppm). Kemudian pemberian IBA pada Ekaliptus konsentrasi 2000 ppm menunjukkan pengaruh terbaik daripada konsentrasi 0, 500, 1000, 4000, dan 8000 ppm (Nababan, 2009), dan hasil uji pendahuluan pada buah naga konsentrasi 2000 ppm menghasilkan pertumbuhan akar optimal daripada konsentrasi 0, 500, 1000, 2000, dan 4000 ppm (Shofiana, Rahayu dan Budipramana, 2013). Dengan konsentrasi yang tepat dan jumlah mata tunas yang tepat, maka penyetekan menggunakan batang dari tanaman ini mampu meningkatkan pertumbuhan untuk ketersediaan bibit tanam.

\section{METODE PENELITIAN}

\section{Bahan}

Penelitian ini dilakukan di Laboratorium Lapangan Terpadu Universitas Lampung. Penelitian ini dilakukan pada bulan April sampai dengan Mei 2019. Bahan yang digunakan pada penelitian ini adalah larutan IBA, setek Indigofera sp., tali, sungkup plastik, polibag, pasir, paranet, label, dan tanah. Sedangkan alat yang digunakan yaitu gunting setek, kertas milimeter blok, timbangan digital, meteran, alat tulis, gunting, oven, kantong kertas, kamera dan sprayer.

\section{Pelaksanaan Penelitian}

Pelaksanaan penelitian dimulai dengan persiapan lahan dan pembuatan sungkup plastik transparan beserta naungan paranet. Kemudian penyiapan media tanam dengan mencuci pasir sungai sebanyak 7 kali. Setelah pasir dicuci, selanjutnya pengisian media tanam tanah subsoil dan pasir dengan volume $(2: 1) \mathrm{ke}$ dalam polibag $14 \times 20 \mathrm{~cm}$. Setelah media tanam siap, setek ditanam yang sebelumnya dicelupkan ke dalam larutan IBA sesuai dengan perlakuan masingmasing selama 5 detik. Bahan setek yang diambil berasal dari indukan yang sama umurnya (2 tahun) dan cabang ortotropnya berumur sama 3 bulan setelah pemangkasan. setelah ditanam, setek disungkup menggunakan plastik transparan. Sungkup dibuka ketika melakukan penyiraman. Namun setelah setek berumur 1 bulan dilakukan pembukaan sungkup secara rutin pada sore sampai pagi hari. Setek diamati dan dipanen secara berkala umur 2,4,6, dan 8 minggu setelah tanam (MST). Peubah pengamatan meliputi persentase setek hidup, persentase setek berakar, persentase setek betunas, jumlah akar, panjang akar, jumlah tunas, panjang tunas, jumlah daun, bobot segar akar, bobot kering akar, bobot segar tunas, dan bobot kering tunas.

\section{Analisis Data}

Rancangan penelitian yang digunakan yaitu Rancangan Acak Lengkap (RAL) yang disusun secara faktorial dengan 2 faktor. Faktor pertama adalah konsentrasi 
(K) IBA cair yang terdiri atas lima taraf yaitu 0 ppm (K0), 500 ppm (K1), 1000 ppm (K2), 1500 ppm (K3), dan 2000 ppm (K4). Faktor kedua adalah jumlah mata tunas (B) yang terdiri dari tiga taraf yaitu setek satu mata tunas (B1), setek dua mata tunas (B2), dan setek tiga mata tunas (B3). Perlakuan yang memiliki sidik ragam yang nyata, dilakukan uji lanjut menggunakan Uji Beda Nyata Terkecil (BNT) dengan taraf $\alpha=5 \%$.

\section{HASIL DAN PEMBAHASAN}

Hasil analisis ragam pada interaksi antara konsentrasi IBA $(0,500,1000,1500$, dan 2000 ppm) dengan jumlah mata tunas (1,2, dan 3 mata tunas) tidak berpengaruh nyata terhadap pertumbuhan setek Indigofer sp. umur 6 dan 8 MST. Dalam penelitian Arinasa (2005) bahwa interaksi antara Rootone-F dan panjang setek pucuk tidak berpengaruh nyata secara signifikan terhadap pertumbuhan Begonia tuberosa Lmk. Hal tersebut dikarenakan cadangan makanan yang tersimpan terbatas sehingga apabila diinteraksikan dengan konsentrasi medium Rootone- $F$ tidak menghasilkan pengaruh yang nyata terhadap variabel yang diamati.

\section{Konsentrasi IBA}

Perlakuan konsentrasi IBA menghasilkan pengaruh nyata terhadap peubah persentase setek berakar, panjang akar primer, jumlah tunas, panjang tunas, bobot segar tunas, dan jumlah daun umur 6 MST. Sedangkan perlakuan konsentrasi IBA umur 8 MST tidak menghasilkan pengaruh nyata terhadap pertumbuhan setek Indigofera sp. yang diduga karena IBA bekerja optimal hanya pada saat umur 6 MST.

Tabel 1 menunjukkan bahwa persentase setek berakar dengan perlakuan IBA pada berbagai konsentrasi menghasilkan pengaruh tertinggi dibandingkan dengan perlakuan tanpa IBA $(0 \mathrm{ppm})$. IBA dapat merangsang pertumbuhan akar terjadi karena adanya rooting factor (auksin) yang akan menstimulir pembentukan akar tersebut (Hartmann, 2014). Panjang akar dengan konsentrasi lebih rendah 500 ppm menghasilkan pengaruh tertinggi dibandingkan dengan kontrol. Hal tersebut diduga peningkatan konsentrasi auksin maka akan menghambat pertumbuhan akar. Pertumbuhan akar akan terhambat dikarenakan jumlah auksin endogen pada bahan setek sudah cukup, sehingga penambahan auksin dengan jumlah yang lebih tinggi pembentukan akar tidak efektif. Keefektifan pada penambahan auksin eksogen hanya terjadi pada konsentrasi tertentu (Firmansyah, Rochmatino dan Kamsinah, 2014).

Peubah jumlah tunas, panjang tunas, bobot segar tunas, dan jumlah daun umur 6 MST perlakuan konsentrasi IBA (500 ppm) menghasilkan rerata tertingggi pada semua peubah pengamatan dibandingkan dengan perlakuan kontrol (Tabel 1). Hasil tersebut diduga karena setek yang menghasilkan panjang akar tertinggi (500 ppm) akan memproduksi sitokinin lebih tinggi. Sitokinin pada akar secara akropetal akan membentuk tunas. Tunas akan menghasilkan daun untuk proses fotosintesis yang menghasilkan karbohidrat sebagai cadangan makanan. Dengan penambahan konsentrasi auksin yang tepat akan menghasilkan pertumbuhan yang optimal. Hal ini diperkuat oleh Wiraswati dan Badami (2018) bahwa setek batang tengah dengan IBA 100 ppm menghasilkan panjang tunas tertinggi. Sedangkan setek bagian tengah dengan konsentrasi lebih kecil 25 ppm menghasilkan nilai tertinggi pada bobot basah 
daun, akar, batang dan bobot kering daun, akar, batang pada tanaman Kumis kucing.

Tabel 1. Persentase setek berakar umur 8 MST, panjang akar primer, jumlah daun, jumlah tunas, panjang tunas, dan bobot segar tunas akibat pemberian konsentrasi IBA umur 6 MST

\begin{tabular}{lrrrrrr}
\hline Peubah Pengamatan & K0 & K1 & K2 & K3 & K4 & $\begin{array}{l}\text { BNT } \\
\mathbf{5} \%\end{array}$ \\
\hline Persentase setek berakar & $4,46 \mathrm{~b}$ & $6,69 \mathrm{a}$ & $6,95 \mathrm{a}$ & $7,50 \mathrm{a}$ & $6,84 \mathrm{a}$ & 1.49 \\
$(\%)$ & $1.21 \mathrm{~b}$ & $1.77 \mathrm{a}$ & $1.52 \mathrm{ab}$ & $1.48 \mathrm{ab}$ & $1.45 \mathrm{ab}$ & 0.34 \\
Panjang akar primer (cm) & $1.18 \mathrm{~b}$ & $1.69 \mathrm{a}$ & $1.46 \mathrm{ab}$ & $1.44 \mathrm{ab}$ & $1.48 \mathrm{ab}$ & 0.32 \\
Jumlah daun (helai) & $1.08 \mathrm{c}$ & $1.62 \mathrm{a}$ & $1.34 \mathrm{abc}$ & $1.25 \mathrm{bc}$ & $1.40 \mathrm{ab}$ & 0.32 \\
Jumlah tunas (tunas) & $1.31 \mathrm{~b}$ & $1.57 \mathrm{a}$ & $1.45 \mathrm{ab}$ & $1.44 \mathrm{ab}$ & $1.45 \mathrm{ab}$ & 0.16 \\
Panjang tunas (cm) & $1.15 \mathrm{~b}$ & $1.42 \mathrm{a}$ & $1.25 \mathrm{~b}$ & $1.27 \mathrm{ab}$ & $1.26 \mathrm{~b}$ & 0.16 \\
Bobot segar tunas $(\mathrm{g})$ & 1.42 &
\end{tabular}

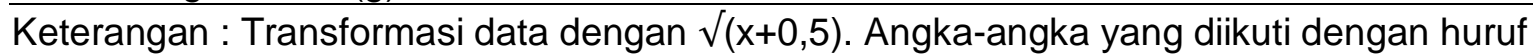
yang sama pada baris yang sama menunjukkan tidak berbeda nyata berdasarkan uji BNT 5\%.

Tabel 2. Pertumbuhan setek Indigofera sp. akibat perlakuan jumlah mata tunas umur 6 dan 8 MST

\begin{tabular}{lccccc}
\hline Peubah Pengamatan & B1 & B2 & B3 & BNT 5\% & $\begin{array}{c}\text { Waktu } \\
\text { Pengamatan }\end{array}$ \\
\hline Jumlah akar primer (helai) & $1,23 \mathrm{~b}$ & $1,49 \mathrm{a}$ & $1,66 \mathrm{a}$ & 0,26 & $6 \mathrm{MST}$ \\
Panjang akar primer (cm) & $1,24 \mathrm{~b}$ & $1,55 \mathrm{a}$ & $1,66 \mathrm{a}$ & 0,26 & $6 \mathrm{MST}$ \\
Jumlah daun (helai) & $1,17 \mathrm{~b}$ & $1,49 \mathrm{a}$ & $1,69 \mathrm{a}$ & 0,24 & $6 \mathrm{MST}$ \\
Jumlah tunas (tunas) & $1,06 \mathrm{~b}$ & $1,39 \mathrm{a}$ & $1,57 \mathrm{a}$ & 0,25 & $6 \mathrm{MST}$ \\
Panjang tunas (cm) & $1,31 \mathrm{~b}$ & $1,46 \mathrm{a}$ & $1,57 \mathrm{a}$ & 0,13 & $6 \mathrm{MST}$ \\
Bobot segar akar $(\mathrm{g})$ & $2,19 \mathrm{~b}$ & $2,66 \mathrm{a}$ & $3,13 \mathrm{a}$ & 0,18 & $6 \mathrm{MST}$ \\
Bobot segar tunas $(\mathrm{g})$ & $1,13 \mathrm{c}$ & $1,28 \mathrm{~b}$ & $1,40 \mathrm{a}$ & 0,12 & $6 \mathrm{MST}$ \\
Bobot kering akar $(\mathrm{g})$ & $0,71 \mathrm{~b}$ & $0,73 \mathrm{a}$ & $0,75 \mathrm{a}$ & 0,03 & $6 \mathrm{MST}$ \\
Bobot kering tunas $(\mathrm{g})$ & $0,72 \mathrm{c}$ & $0,80 \mathrm{~b}$ & $0,90 \mathrm{a}$ & 0,08 & $6 \mathrm{MST}$ \\
\hline Jumlah akar primer (helai) & $1,53 \mathrm{~b}$ & $1,94 \mathrm{a}$ & $1,98 \mathrm{a}$ & 0,23 & $8 \mathrm{MST}$ \\
Panjang akar primer (cm) & $2,11 \mathrm{~b}$ & $3,38 \mathrm{a}$ & $3,41 \mathrm{a}$ & 0,63 & $8 \mathrm{MST}$ \\
Jumlah daun (helai) & $1,28 \mathrm{c}$ & $2,71 \mathrm{~b}$ & $3,03 \mathrm{a}$ & 0,42 & $8 \mathrm{MST}$ \\
Jumlah tunas (tunas) & $0,88 \mathrm{c}$ & $1,46 \mathrm{~b}$ & $1,68 \mathrm{a}$ & 0,17 & $8 \mathrm{MST}$ \\
Panjang tunas $(\mathrm{cm})$ & $1,46 \mathrm{c}$ & $2,32 \mathrm{~b}$ & $2,51 \mathrm{a}$ & 0,26 & $8 \mathrm{MST}$ \\
Bobot segar akar $(\mathrm{g})$ & $0,86 \mathrm{~b}$ & $1,19 \mathrm{~b}$ & $1,31 \mathrm{a}$ & 0,17 & $8 \mathrm{MST}$ \\
Bobot segar tunas $(\mathrm{g})$ & $1,02 \mathrm{c}$ & $1,73 \mathrm{~b}$ & $2,08 \mathrm{a}$ & 0,26 & $8 \mathrm{MST}$ \\
Bobot kering akar $(\mathrm{g})$ & $0,73 \mathrm{c}$ & $0,77 \mathrm{~b}$ & $0,80 \mathrm{a}$ & 0,03 & $8 \mathrm{MST}$ \\
Bobot kering tunas $(\mathrm{g})$ & $0,79 \mathrm{c}$ & $0,98 \mathrm{~b}$ & $1,12 \mathrm{a}$ & 0,09 & $8 \mathrm{MST}$ \\
\hline Persentase setek berakar & $4,01 \mathrm{~b}$ & $7,43 \mathrm{a}$ & $8.02 \mathrm{a}$ & 1.15 & $8 \mathrm{MST}$ \\
Persentase setek hidup & $36,67 \mathrm{~b}$ & $85,00 \mathrm{a}$ & $91.67 \mathrm{a}$ & $13.04 \mathrm{a})$ & $8 \mathrm{MST}$ \\
Persentase setek bertunas & $2,27 \mathrm{~b}$ & $3,02 \mathrm{a}$ & $2.84 \mathrm{a}$ & 0.45 & $8 \mathrm{MST}$ \\
\hline
\end{tabular}

Keterangan : Transformasi data dengan $\sqrt{ }(x+0,5)$ dan ${ }^{\text {a) }}$ merupakan data asli. Angka-angka yang diikuti dengan huruf yang sama pada baris yang sama menunjukkan tidak berbeda nyata berdasarkan uji BNT 5\%.

\section{Jumlah Mata Tunas}

Perlakuan jumlah mata tunas menghasilkan pengaruh nyata terhadap semua peubah pengamatan umur 6 dan 8 MST. Umumnya pada setek berumur 6 MST dengan perlakuan 2 dan 3 mata tunas menghasilkan pengaruh perlakuan terbaik dibandingkan setek 1 mata tunas. Sedangkan ketika setek berumur 8 MST umumnya 
setek 3 mata tunas menghasilkan perlakuan terbaik, diikuti oleh setek 2 mata tunas, dan terendah setek 1 mata tunas (Tabel 2).

Jumlah mata tunas berkaitan dengan jumlah karbohidrat yang terkandung di dalam bahan tanam. Pada batang setek terdapat karbohidrat yang merupakan cadangan makanan setek. karbohidrat dimanfaatkan untuk pembentukan sel baru sehingga terbentuk akar dan juga tunas. Akar dan juga tunas terbentuk akibat kondisi yag kurang menguntungkan pada setek sehingga karbohidrat digunakan untuk membentuk sel baru (Chun et al. 2003).

Pada peubah persentase setek hidup (Tabel 2), tanaman yang hidup merupakan tanaman yang menghasilkan akar dan juga tunas. Sedangkan kematian diakibatkan oleh tidak terbentuknya tunas dan juga akar. Dapat dilihat pada Gambar 1 bahwa setek dengan 1 mata tunas umur 6 MST pada IBA (1000 dan 2000 ppm) menghasilkan akar. Sedangkan perlakuannya lainnya mengalami kematian. Kebanyakan kematian diperoleh pada perlakuan setek 1 mata tunas. Setek 1 mata tunas menghasilkan jumlah karbohidrat yang lebih rendah dibandingkan setek dengan 2 dan 3 mata tunas. Dapat dilihat pada Gambar 2 (a dan b) bahwa setek 2 dan 3 mata tunas pada setiap perlakuan dapat menghasilkan akar dan tunas.
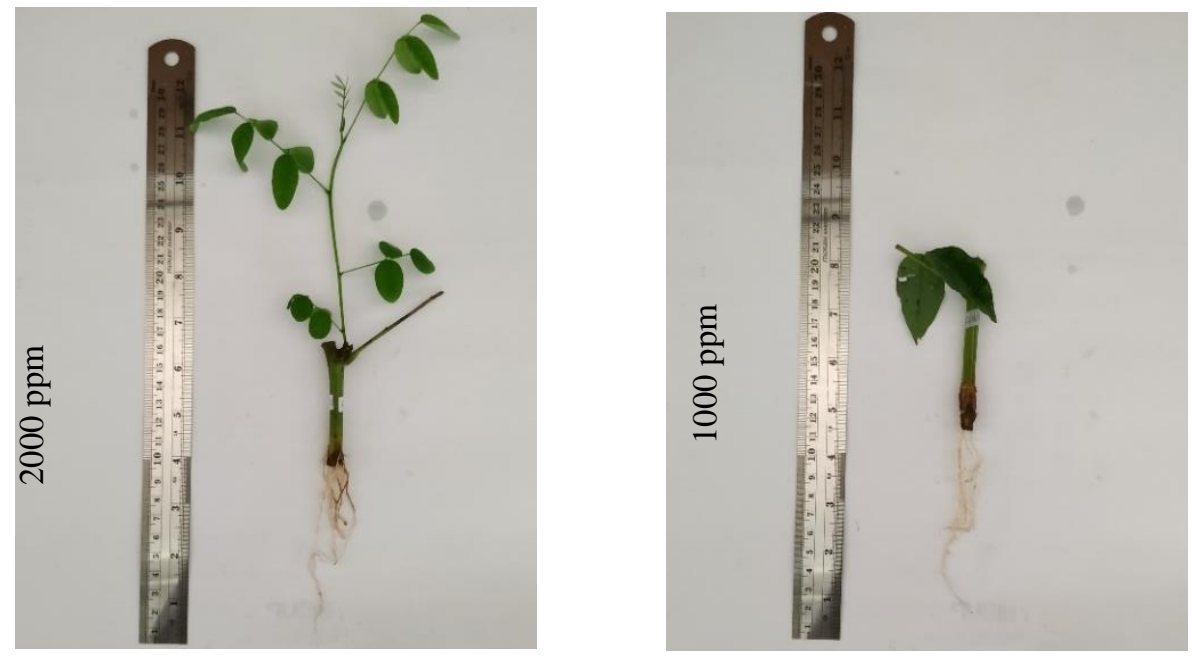

Gambar 1. Setek 2 mata tunas Indigofera sp
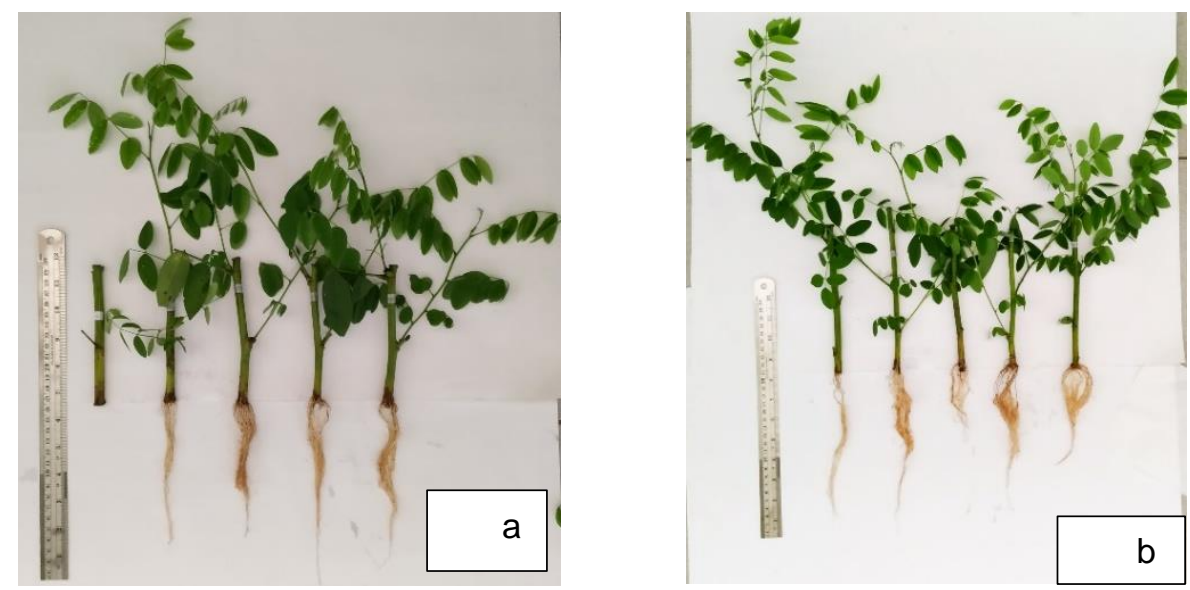

Gambar 2. Setek 2 mata tunas Indigofera sp. a), Setek 3 mata tunas Indigofera sp b).

Urutan gambar a atau b dari kiri ke kanan (0, 500, 1000, 1500, dan 2000 ppm)

Kemampuan bertahan hidup pada setek dipengaruhi oleh terbentuknya akar dan juga tunas. Penyerapan air dan unsur hara merupakan fungsi dari akar, 
sedangkan tunas merupakan tempat terjadinya proses fotosintesis yang menghasilkan karbohidrat. Karbohidrat tersimpan di semua bagian vegetatif tanaman sebagai cadangan makanan. Kematian setek diakibatkan oleh tidak terbentuknya akar dengan fungsinya, kemudian daun pada tunas juga akan menghasilkan karbohidrat yang diedarkan ke seluruh sel untuk pertumbuhan sehingga setek mampu bertahan hidup. Untuk itu perlu diketahui faktor keberhasilan setek. Keberhasilan setek tergantung beberapa faktor dalam dan faktor luar. Faktor dalam diantaranya adalah kondisi fisiologi setek, waktu pengumpulan setek, hormon endogen, dan lainnya. Adapun yang termasuk faktor luar antara lain adalah suhu, media perakaran, kelembaban, intensitas cahaya dan hormon pengatur tumbuh (Chun et al. 2003; Na'iem, 2000).

\section{SIMPULAN}

Berdasarkan penelitian yang dilakukan dapat disimpulkan bahwa: Konsentrasi IBA berpengaruh nyata terhadap persentase setek berakar umur $8 \mathrm{MST}$, panjang akar primer, jumlah daun, jumlah tunas, panjang tunas, dan bobot segar tunas umur 6 MST. Sedangkan jumlah mata tunas sebanyak 2 dan 3 mata tunas menghasilkan rerata umum tertinggi dibandingkan dengan setek 1 mata tunas pada semua peubah pengamatan.

\section{DAFTAR PUSTAKA}

Arinasa, IBK. 2015. Pengaruh konsentrasi Rootone-F dan panjang setek pada pertumbuhan Begonia tuberosa Lmk. Jurnal Hortikultura 2(25): 142-149.

Badan Litbang Pertanian. 2011. Tanaman Indigofera sp. untuk Ternak Kambing. Agroinovasi., edisi 14-20 (3435): 12-13.

Christiana, M.D. 2018. Pengaruh perlakuan skarifikasi terhadap kualitas benih Indigofera sp. Skripsi. Bandar Lampung: Universitas Lampung.

Chun, T., S. Taketa, S. Tsurumi, dan M. Ichii. 2003. The effects of auxin on lateral root initiation and root gravitropism in a lateral rootless mutant Lrt1 of rice (Oryza sativa L.). Kluwer Academic Publisher 39: 161-170.

Dirr, M.A. and Heuser Jr., C.W. 2006. The Reference manual of woody plant propagation: from seed to tissue culture (second edition). pp. 410, Portland: Timberr press.

Firmansyah, S. F. Rochmatino, dan Kamsinah. 2014. Pengaruh pemberian komposisi media terhadap pertumbuhan setek Sanseviera cylindrica var. patula. Scripta Biologica 1(2): 161-165.

Hartmann, H.T, Kester, D.E., Davis Jr. F.T., and Geneve, R.L. 2014. Plant propagation: principles and practices (eigth edition). pp. 922 United States of America: Pearson.

Haseen A., "Pieterse, P.A., and Rehman, N.F.G. 2004. Effect of pre-planting seed treatment on dormancy breaking and germination of Indigofera accesi. Journal Tropical Grasslands 38: 154-157.

Hassen, A., Rethman, N.F.G., and Apostolides, Z,. 2006. Morphological and agronomic characterization of Indigofera species using multivariate analysis. Tropccal Grasslands 40: 45-59. 
Hassen, A., Rethman N.F.G., Van Niekerk, and Tjelele, T.J. 2007. Influence of season/year and species on chemical composition and in vitro digestibility of five indigofera accessions. Journal Animal Feed Scence Technology 136: 12-322.

Herdiawan, I., Abdullah, L, dan Sopandi, D. 2014. Status Nutrisi Hijauan Indigofera zollingeriana pada Berbagai Taraf Perlakuan Stres Kekeringan dan Interval Pemangkasan. Jurnal Ilmu Ternak dan Veteriner 2(19): 91-103.

Nababan, D. 2009. Hasil Penelitian: Penggunaan hormon iba terhadap pertumbuhan setek Ekaliptus Klon IND 48. Medan: USU Repository.

Na'iem, M. 2000. Prospek Pertumbuhan Klon Jati di Indonesia. Seminar Nasional Status Silvikultur 1999. Yogyakarta: Fakultas Kehutanan Universitas Gadjah Mada.

Ningsih, A.S.W. 2017. Pengaruh pemberian Rootone-f, urin sapi, kecambah kacang hijau (tauge), dan bawang merah terhadap keberhasilan pertumbuhan setek batang Nyawai (Ficus variegata blume). Skripsi UIN Sunan Kalijaga: 2-3.

Ramadiana, S. 2008. Prosiding Seminar Hasil Penelitian dan Pengabdian kepada Masyarakat: Respon pertumbuhan setek lidah mertua (Sansevieria trifasciata var. Lorentii) pada pemberian berbagai konsentrasi IBA dan asal bahan tanam. Bandar Lampung: Universitas Lampung.

Sandra, E. 2010. Peranan Zat Pengatur Tumbuh dalam Kultur Jaringan. Jakarta: Esha Flora.

Schrire B.D., Lavi, M., Barker, N.P., and Forest, F. 2009. Phylogeny of the tribe Indigofereae (leguminosae- apilionoideae): Geographically structured more in succulent-rich and temperate settings than in grass-rich environments. American Journal Botany 96(4): 816-852.

Shofiana, A. Rahayu, Y.S., dan Budipramana, L.S. 2013. Pengaruh pemberian berbagai konsentrasi hormon IBA (indole butyric acid) terhadap pertumbuhan akar pada setek batang tanaman buah naga (Hylocereus undatus). LenteraBio 1(2): 101-105.

Tresniawati, C. dan Saefudin. 2006. Prosiding Lokakarya II Status Teknologi Tanaman: Pengaruh Panjang dan Diameter Setek terhadap Pertumbuhan Bibit Jarak Pagar (Jatropha curcas L.). Jarak Pagar (Jatropha curcas L.). Bogor: Pusat Penelitian dan Pengembangan Perkebuanan : 249-252.

Wattimena, G.A. 1992. Bioteknologi tanaman I. Pusat Antar Universitas Bioteknologi, Institut Pertanian Bogor $455 \mathrm{hlm}$.

Wiraswasti, S.K. dan Badami, K. 2018. Pengaruh Pemberian IBA dan Asal Setek Terhadap Pertumbuhan Vegetatif Kumis Kucing. Agrovigor 11(2): 65-70. 